\title{
Needs Analysis of Interactive Audio Visual Media Development in Speaking Course at Islamic Universities
}

\author{
${ }^{1 s t}$ Umi Faizah, \\ Universitas \\ SebelasMaret
}

\author{
${ }^{2 n d}$ Sarwiji Suwandi \\ Universitas \\ SebelasMaret
}

\author{
${ }^{3 r d}$ Andayani, \\ Universitas \\ SebelasMaret
}

\author{
${ }^{4 \text { th }}$ Ani R \\ Universitas \\ SebelasMaret
}

\author{
5th Bagiya,
Universitas \\ SebelasMaret
}

\author{
${ }^{6 \text { th }}$ Kadaryati \\ Universitas \\ Muhammadiyah \\ Purworejo
}

\begin{abstract}
The purposes of this study are to describe: 1) the use of instructional media in speaking courses, 2) problems/constraints faced by lecturers in the teaching of speaking course, and 3 ) forms of learning media that need to be developed in speaking course. Data collection techniques are carried out by using survey technique covering observations and interviews. Data are analyzed by using descriptive analysis. The results of this study are: 1) there have been several media used in speaking course namely puppets, puppets, cards, YouTube, pictures, and books; 2) there are many constraints faced in learning-teaching activities,i.e. lecturers do not have interactive audiovisual media compiled collaboratively with their students, students need audio visual media as a trigger in speaking activities, and lecturers need integrated media with learning approaches;and 3) mediawhich needs to be developed in speaking course in line with obtaining basic competenceof da'wah rhetoric is interactive audio visual media.
\end{abstract}

Keywords: needs, interactive audio visual media, Speaking Course, Islamic Universities

\section{INTRODUCTION}

Media and learning like betel are halved. Both will meet each other in order to deliver learning material. Media as a communication tool in learning is very helpful for educators in conveying information to students. Media is something that carries information between the source and receiver of information (Heinich et al. 1985). The use of technology-based media is now the main attraction. Information technology makes changes and shifts in the educational paradigm (Sanaky, 2009).

In some Islamic universities the use of media is still dominated by media manuals. The lack of touch of technology is a lack of attractiveness for students. An integrated learning approach with the media has not been used in learning. Integration between the media and the learning approach will facilitate understanding of material comprehensively.

Interactive audio-based learning media can be used to support students' speaking competence.

Through speaking courses students can actualize themselves in various activities in the community. Speaking courses become compulsory subjects in several Islamic Universities in the Indonesian Language and Literature Education Study Program. Variations in the name of the course are adjusted to the purpose of the speaking activity. In general, specialization in the competence of speaking propaganda has not been included in the teaching of speaking. Speaking of da'wah or can be called the da'wah rhetoric a strategic competence as a student at PT Islam. The da'wah rhetoric is to inform Muslims about the faith and teachings of Islam with wisdom in Arabic / Quran(Don et al., 2012).

. Da'wah can also be interpreted as being willing to accept the guidance of Islam by increasing the level of faith and devotion, being indulgent in makruf and nahimungkar (Sholeh, 2013: 48-50). To improve the competence of rhetoric, da'wah requires an integrated media with learning approach.

The scientific approach can be coupled with learning media to improve rhetorical competence, especially da'wah. Stimulation of learning media combined with learning approaches can improve the competence of rhetoric. Learning with a scientific approach is learning that consists of observing activities (to identify things you want to know), formulating questions (asking) (and formulating hypotheses), trying / collecting data (information) and drawing conclusions and communicating results that consist of conclusions to obtain knowledge, 
skills and attitudes. These steps can be continued with creating activities (Ridwan, 2014).

The limited use of technology-based learning media in several Islamic universities is the background for the preparation of interactive audio-visual learning media based on scientific approaches. Expectations in several Islamic Universities are the fulfillment of technologybased media sharing that supports speaking competence called interactive audio visual learning media based on scientific approaches in rhetoric courses (speaking).

\section{METHODS}

The object of this study is the analysis of the needs of learning media in speaking courses. Research subjects were students and lecturers in Central Java and DIY Islamic Universities. Research settings are at Muhammadiyah University Purworejo (setting I), Muhammadiyah University Purwokerto (setting II), Muhammadiyah University Surakarta (setting III), and Ahmad Dahlan University (IV setting). Collecting data by observation, interviews and questionnaires. Data analysis is qualitatively descriptive according to data in the field.

\section{RESULTS AND DISCUSSION}

\section{(1) Use of Media in Speaking Courses}

All settings carry out learning with the same system, namely by giving theory in advance and then carrying out the practice to support the theory and stabilization in the mastery of speaking material. Generally the material presented is in the form of speaking material which includes the notion of speaking, the purpose of speaking, the type of speaking, the method of speaking and the techniques of speaking, while for practice it has varied, namely there are those who do storytelling, storytelling, lecturing and talking politics.

From all observations in a number of PTs and interviews with lecturer informants, it was found that learning should proceed with a two-way system, namely lecturers providing material and students also active in learning both question and answer and practice. The clutter in learning is the absence of learning media that is integrated with the learning approach.

The use of learning media in setting 1 is based on interviews with lecturers of courses talking Media NS which is used as a complement to learning in the form of dolls, puzzles, luck circles, lucky pockets and pictures. It was further explained that puppets and puppets were used in storytelling and storytelling, picture media was used for tour guide materials, Q-Cards were used for the learning of event bearers and entrepreneurship. Audio visual media at all, for you tube also has not been used optimally in speaking learning (CLHW 1).
Then in setting 2 based on interviews with the lecturers of SF rhetoric speaking courses it was stated that the media used was youtube. Also explained in the field notes the results of the interviews of 2 media used in the form of speaking activities of a character who has been downloaded and then analyzed both in language, and nonlanguage by students. The media gap that has not been used is interactive audio visual learning media. Based on interviews with lecturers that the media used are generally still downloading from the internet. This is due to the lack of opportunities available to make learning media collaborate with students (CLHW 2).

In contrast to setting 3 based on interviews with lecturers of AHP speaking courses, it was explained that the media used were laptops and hand pones. Laptops and hand pones are used to record student speaking activities and then are appreciated to be appreciated jointly by lecturers and students in linguistic and non-linguistic terms. Based on the information from the informants at the university, there were no learning media in speaking courses that were integrated with the learning approach (CLHW 3).

The next information is the fact that occurred in setting 4 obtained by the media information used in learning is a doll or paper used to tell stories with the characters of each character. In addition, it was also explained that the media used by downloading videos of Uje characters, AA Gym, Soekarno as learning material. Learning media integrated with learning approaches have not been used at the university (CLHW 4).

\section{(2)Constraints faced by lecturers in teaching speaking courses}

As an Islamic Higher Education that should uphold its Islamic values, it is necessary to support the emergence of competency in speaking da'wah. Basic da'wah competence has not been raised in the speaking course, except in setting 4 which states explicitly in the RPS. Therefore, the emergence of the basic competence of da'wah rhetoric in speaking courses can be applied. The use of learning media in several Islamic Universities in Central Java in the form of audio visuals is still minimal. This is suspected because lecturers have not been able to make the media independently or collaboratively with students. Audio visual media that is a favorite for use is download from youtube.

The absence of collaboration between lecturers and students makes the design of learning media to be a monopoly of lecturers or even monopoly of students. Media created by students without involving lecturers still has shortcomings. Likewise, learning media created by the lecturers themselves are considered to be one-way learning. The absence of integration between the media and the learning approach. In the learning system the role of media 
and learning approaches greatly influence the success of learning.

\section{(3) Forms of media that need to be developed in speaking courses}

The most dominant media favored by students is interactive audio visual media that combines images and music. Media defense that can accommodate da'wah activities is an interactive audio visual learning media. This media is used to stimulate speech competency, which is a mini film feature in it as a stimulus for diction contained in the film. Learning steps with a scientific approach combined in the media will activate students.

The first step is to observe the following mini films! Next came a 20-minute film about the Bidikmisi students who struggled to finish their studies in order to make their parents happy, but he had to accept the bitter truth when his mother passed away before he described his graduation! for small themes and topics. In the second stage the questioning phase comes up, please ask questions related to the mini film! The third stage explores the phrase "please search for material from the Koran, hadiths, books and the internet on selected topics or themes! The fourth stage associates the sentence appears "please connect the material with the reference obtained by completing it with the arguments of the Qur'an and hadith by making a draft in writing. The fifth stage communicates that is the rhetoric of da'wah with the Indonesian language that is good and right equipped with the arguments of the Qur'an and hadith.

\section{IV.CONCLUSIONS}

The results of this study are: (1) The use of instructional media in the courses talking include dolls, puppets, youtube, lap top and cellphones, (2) the obstacles faced by lecturers in learning are not yet integrated between learning media and learning approaches, ( 3 ) forms of learning media that need to be developed are interactive audio visual learning media in the teaching of da'wah rhetoric.

\section{REFERENCES}

Don, A. G., Muhamat Kawangit, R., Hamjah, S. H., Md.Sham, F., Mohd.Nasir, B., Asha'ari, M. F., ... Abd Ghani, M. Z. (2012). Da'wah through social services method: The experience of the department of da'wah and leadership studies, National University of Malaysia. Advances in Natural and Applied Sciences.

Heinich Robert, Molenda, Michel. Russel James D. (1985). Intructional and the New Technologies of Instruction. New York: John Willley \& Sons.

Ridwan, A. (2014). Pembelajaran Saintifik untuk Implementasi Kurikulum 2013. (S. Yayat, Ed.).
Jakarta: PT Bumi Aksara., (July 2014).

Sanaky, H.AH.(2009). Media Pembelajaran. Yogyakarta: SafiriaInsania Press.

Sholeh, R. (2013). ManajemenDakwahMuhammadiyah. Yogyakarta: SuaraMuhammadiyah. 